IBIMA Publishing

Journal of Southeast Asian Research

http://www.ibimapublishing.com/journals/JSAR/jsar.html

Vol. 2013 (2013), Article ID 432043, 10 pages

DOI: $10.5171 / 2013.432043$

Research Article

\title{
Indicators in the Purchase of Housing Properties
}

\author{
Uchenna Cyril Eze ${ }^{1}$ and Yih Ying Lim ${ }^{2}$ \\ ${ }^{1}$ Division of Business and Management, United International College (UIC), Beijing Normal \\ University-Hong Kong Baptist University, Tangjiawan, Zhuhai, Guangdong, China \\ ${ }^{2}$ Faculty of Business, Multimedia University, Melaka Campus, Bukit Beruang, Ayer Keroh Lama, \\ Melaka, Malaysia
}

Correspondence should be addressed to: Uchenna Cyril Eze; uchennaeze@uic.edu.hk

Received 16 February 2013; Accepted 15 July 2013; Published 28 November 2013

Copyright (C 2013 Uchenna Cyril Eze and Yih Ying Lim. Distributed under Creative Commons CC-BY 3.0

\begin{abstract}
This paper examines the effects of key indicators (risk of inflation, inflation hedge, property prices, real income of investors, access to financing, and interest rates) on investors' investors' decision to purchase a real estate property. The data for this study were obtained by conducting a detailed literature review on the key indicators and relevant theories. The outcome of this paper is a conceptual framework of the proposed ideas. We hope that this critical review will provide relevant materials for the real estate industry as well as researchers to build capacity, and knowledge in developing relevant scales and measures for future assessments of purchase decisions involving real estate property.
\end{abstract}

Keywords: Real estate, purchase decision, conceptual framework, key indicators, investors, Malaysia.

\section{Introduction}

A piece of real estate is a unique and heterogeneous asset involving crossdisciplinary fields (Boon 2005). According to Tharatchai (2009), real estate is one of the most significant asset classes, contributing significantly to the national economy, involving building, machinery, the acquisition of various property rights and others. Nevertheless, the most common related terms of real estate in this study is building, which is typically classified in two categories: residential property and commercial property (Christudason 2004). The banking and finance and the real estate industries are interdependence, and involves a cause- consequences relationship where one tends to lead to another (Chen et al. 2004).

According to Dunhill (2009), in recent years, the property in Malaysia is getting a lot of attention both from local and foreign investors. Many are still puzzled about the factors necessary to sustain its growth, and in the process questions the increasing property prices. This attention is enabled by the government's efforts to promote foreign investment by allowing more projects and structures to be developed in Malaysia, especially in the mid-year 2009, when the government injected the stimulus package worth RM650 million into the construction sector by creating more projects and infrastructures for residents.

Cite this Article as: Uchenna Cyril Eze and Yih Ying Lim (2013), "Indicators in the Purchase of Housing Properties," Journal of Southeast Asian Research, Vol. 2013 (2013), Article ID 432043, DOI: 10.5171/2013.432043 
This effort is included in the Ninth Malaysian Plan as the Malaysian government wanted to attract more foreign investors. The plan appears to be successful as there is increasing evidence that more investors (local and foreign) were actively involved in real estate investment.

Apart from this, studies of this nature can enhance consumers' purchase behavior by making essential knowledge accessible to relevant consumers (Wells 1993; Eze et al. 2012; Eze et al. 2011). This paper could help the banking industry and the property sector by understanding their perceptions on the investment decisions as real estate investment requires heavy commitment in financial terms. Additionally, this sector has attracted the attention of investors around the world, but what appears to be missing is the lack of knowledge on major financial and economic indicators considered critical to prospective investors (Bunton 2008).

There are very few researches on real estate industry in Malaysia. From previous research, Clayton et al. (2008) found that the difficulty in this area of study is partly due to data limitations. In addition, real estate is a subjective research area because of the volatility of the industry. Sipan et al. (2005) work also reflected on the research issues in conducting related studies. The property market began commercialization in 2006, when real estate investors began investing. Thus, the data for overall property types were available as the government wanted to encourage foreign investors to invest in real estate market in Malaysia.

In addition, prior research emphasized the dynamic changes of property prices as a key concern. Meanwhile, the insights of the influences on the decision to buy a property include interest rates, inflation, mortgage rates and real income. This paper focuses on key elements in investors decisions to purchase a property: risk and return of investment, inflation, property prices, interest rates, mortgage rates and real income; therefore, prior studies in this field are inherently complexity, which could make applying their findings challenging as the property prices are interrelated with other possible determinants (Hui 2008; Liow et al. 2006).

\section{Conceptual Development}

The purpose of real estate investment is to gain profit to compensate the cost of forgoing present consumption (Shim et al. 2008). According to Corgel et al. (1998), real estate could be viewed from four perspectives: investment, market, mortgage finance, and legal, which aid investors in implementing and analyzing real estate decisions. In this case, this study focuses on investment perspective, as real estate decision-making centers on investment valuation, which involves cash flows and valuations to understand the value and maximize investors' wealth (Corgel et al. 1998).

Investors acquire property with the hope of generating periodic income for a considerable period and owner-occupiers, as the term implies, are those who buy properties in view of a long period of holding. Thus, every aspect is vital for determining the growth and health of property investment in Malaysia. Real estate in Malaysia today is booming as Malaysia has great potential to bring enormous returns for both local and foreign investors. Furthermore, the emerging Malaysia's economy had drawn investors' attentions globally; putting their investment in Malay2001 Asia seems to be an intelligence decision.

Over the years, the housing prices in Malaysia have gradually increased, especially after 2000 due to the economic recovery from the 1997 Asian Financial crisis. This has attracted the attention of investors to multiply their wealth creation options in Malaysia. Another boost in this process was because Malaysia's currency, the Ringgit (RM), was 53 percent undervalued compared to the U.S. dollar as of July 2000, according to the Big Mac Index published by The Economist (2001). According to Davidson (2008), the editor of The Expat, and manager of the Malaysia My Second Home website, within the five years plan, Malaysia has enjoyed a fairly 
and steady economic growth since the 1970s. However, he also mentioned that lack of domestic consumption could be a cause for concern for investors.

Overall, the advantages of investing in real estate seem to outweigh the disadvantages. It appears investing in real estate in Malaysia would be a sound decision. In addition, the government is now actively encouraging foreigners to buy properties in country. In the past, the government placed restrictions on foreign buyers but now, nearly all barriers have been removed. With stable politics, harmony among citizenry, high literacy rate, strong economic growth, established statutory laws on ownership and title deeds, and strategic location; this appears to be an alternative approach to diversify the investment risk and maximizing wealth for the nation and wealth creators. Figure 1 shows the conceptual framework of this research.

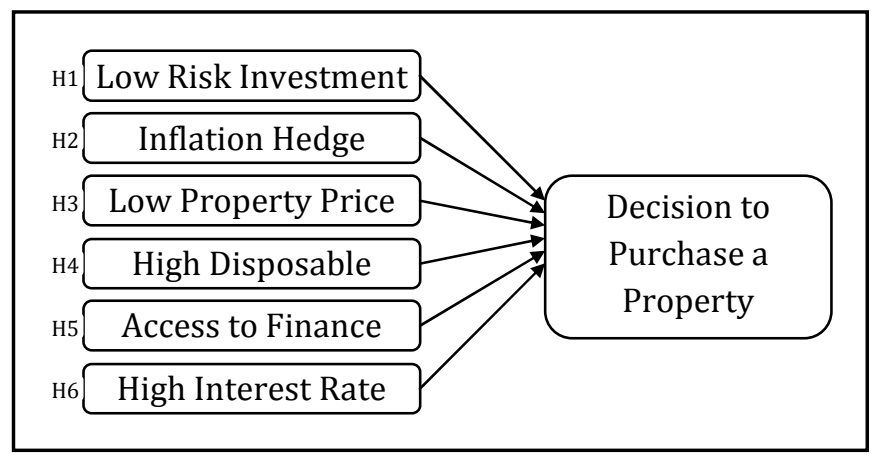

Figure 1: Conceptual Framework

\section{Risks of Investment}

According to Corgel et al. (1998), risk preferences cannot be ignored in the development of investment philosophy, objectives and policies. In general, there are three types of risk preferences; riskloving, risk-neutral and risk-averse.

Iossifov et al. (2008) indicated that investors often misunderstand the positive relationship between risk and return. Undertaking a riskier investment does not guarantee a higher return. In fact, there is some probability that investors will realize lower returns on the riskier investments than on the less risky alternatives. Compensation for accepting riskier investments comes in the form of higher expected rates of return at the time of purchase (Corgel et al. 1998). Real estate investors generally face two sources of risk: (1) the risk associated with uncertain outcomes, given a known probability distribution, and (2) the additional risk that results from the fact that the assumed distribution may itself be incorrect. The findings from Sahni \& Phadnis (2008) would be discrete on risks in real estate; for instance, liquidity risk, regulatory risk, property market transaction-risk, and macroeconomics risk. All these risks are crucial for understanding events that might occur in the country. Unfortunately, Sahni and Phadnis's (2008) report can only be applied in India, as the availability of raw data in Malaysia may be a challenge. Hence, several risks such as liquidity risk and macroeconomic risk can be applied in this study, because liquidity risk and macroeconomic risk are the general indicators that are associated with financial and economic indicators. These are important indicators for investors concerning the country's current economy health. Hence, the following hypothesis:

H1: Low risk of investment will have a positive influence on investors' decision to purchase a property.

\section{Inflation Hedge}

Inflation entails the changes in Consumer Price Index (CPI), which measures the 
retail prices of a fixed "market basket" of several thousand goods and services purchased by households. Inflation hedge can be defined as an investment design to protect oneself from investment risk. Liow et al. (2006) identified two types of inflation: (1) expected inflation, and (2) unexpected inflation. Prior research indicates that inflation hedge as an asset, especially in real estate (Fama \& Schwert 1977). However, other studies find that real estate fails to hedge against unexpected inflation (Brueggeman et al., 1984). In addition, real estate has been found to provide no effective inflation hedge (Glascock \& Davidson 1995).

Ibrahim et al. (2009) concluded that investment in real estate is a good hedge against inflation, as the price appreciation of the properties will be able to offset the impact of increasing inflation. Inflation has direct effects, not necessarily positive, on the real the value of housing. Inflation induces nominal capital gains, which are not real gains but are nonetheless taxed (at capital gains rates, especially in the U.S.) when houses are sold. This suggests that inflation might reduce the turnover rate of housing as owners postpone gains realizations (Pukthuanthong-Le \& Roll 2009).

Based on Toscano (2007) and Petrov (2008) studies, it is emphasized that inflation rate tends to have no impact on investors' decision-making for a property. Hence, the proposed hypothesis:

H2: Inflation hedge will have a negative influence on investors' decision to purchase a property.

\section{Property Prices}

Since most people's budgets are limited, price is probably the most important aspect in the decision-making process of buying a property (Mattiasson \& Rönnqvist 2009). Price expectation and fluctuation in residential property prices tend to have more effect on property prices, probably due to poor planning and infrastructure developments, administrative bottlenecks, problems on property rights, or inefficient and inequitable land distribution (Wong \& Hui 2008; Glindro et al. 2008; Ballesteros 2002). Good examples would be China, Hong Kong, and to a lesser degree, Malaysia, currently facing property bubble and is on the verge to burst, which could see prices jump more than 50 percent in a short time (Mufson 2010).

Irrespective of investors' nationality, they still tend to perceive property price as one of the determinants of buying a housing property as it involves a huge monetary investment. In addition, it involves the property's affordability to invest in the market (Shuid 2004; Hood 1999). Hence, the proposed hypothesis:

H3: High property prices will have a positive influence on investors' decision to purchase a property.

\section{Disposable Income of Investors}

La Paz (2003) discussed the income that affects decision-making as 'normal' income and it enables a household (or not) to buy a property. He defined 'normal' income as the wage and the total amount of wages that a family earns including those proceeds from overtime. In the model, levels of earning have been discriminated in order to capture the relationships derived from high or low levels of income.

Wong (2009) depicted the real income as those that most middle-income earners will own including one or two properties to help finance their children's education or their aging parents (Poong et al. 2009). Typically, the older generation would not have purchased life insurance, as it may not be that popular. On the other hand, Opoku and Abdul-Muhmin (2010) indicated that household income these days are unhealthy unlike during the oil boom years of the 1970s. In general, the rise of oil prices causes high inflation affecting purchasing power. Normally, people in the lowest income bracket are likely to opt for apartments (Opoku \& Abdul-Muhmin 2010).

Tan (2008) revealed that the real income actually plays an important role in 
households as it indicates investors' capability to afford property and other assets. Higher income tends to influence the mobility of households as higher income clearly widens the likelihood of moving into larger and better houses (Tan, 2008). Shuid (2004) managed to express some concern on the low medium income in Kuala Lumpur's population with a percentage of $20.5 \%$. However, he admitted that in reality there are many people in the category struggling to own a house due to the rising cost of living in the country.

As noted earlier, prior research indicate that real income and disposable income can influence investors' decision-making process to buy a property as they define investors' capability to afford real estate investment. Hence the proposed hypothesis:

H4: High disposable income will have a positive influence on their decision to purchase a property.

\section{Access to Financing}

According to Allen and Gale (2000), in times of uncertainty, borrowers would be motivated to borrow to invest in less risky assets (e.g. real estate), an action, which raises demand for such assets and drives up prices. They also stressed that when prices appreciate; there would be opportunity for profit taking for the investor: Properties may be sold at higher prices and the proceeds from the sale could be more than sufficient to service the initial mortgage. La Paz (2003) concluded that a potential investor would not enter the market unless the investor had obtained the necessary credit to finance the investment (Eze 2004).

Malaysian banking institutions offer two types of mortgage loans: conventional housing loans and Islamic house financing. Islamic house financing products generally share the same characteristics as normal housing loan products but are based on the concept of Bai Bithaman Ajil (BBA). BBA or Deferred Payment Sale refers to the sale of goods on a deferred payment basis at a price that includes a profit margin agreed upon by both the buyer and the seller. Islamic house financing is mostly fixed rate financing, but as of 2003, banking institutions have begun to offer variablerate Islamic house financing products. Mortgage securitization has been the domain of the National Mortgage Corporation (Cagamas), which was set up in 1988. Cagamas is the main issuer of mortgage-backed up securities by housing loans purchased from the banking institutions. Cagamas not only catalyzed the expansion of the Malaysian mortgage market, but also encouraged the increased participation of banking institutions in the market. Prior to the advent of securitization, banks were less than eager to extend housing loans. (Glindro et al. 2008).

The availability and smooth process of requesting loan enable investors to obtain house financing. Tan's (2008) study unveiled that the mortgage or financing of the property should be extended to aid the potential investors or house owner to own a property or home, which requires the government to increase the availability and alternative of loans or mortgages from the aid of Employment Provident Fund (EPF). However, it still depends on the financing institutions and regulations to approve the financing. As stated by Kamarudin and Lim (2005) the restriction of the loan regulations will affect property market activity by tightening credits in Malaysia. This study examines the availability and the ease of obtaining mortgage financing, as the rates are similar to interest rates. The ease of obtaining mortgage financing is considered a key factor in investors' decision to buy a property. Hence, the proposed hypothesis:

H5: Access to finance for investors will have a positive influence on their decision to purchase a property.

\section{Interest Rates}

According to Mera and Renaud (2001) based on basic macroeconomics criteria, the moment the central bank increases interest rates, investors tend to be cautious 
about deciding to buy a property as it involves heavy leverage and include taxes as well. Therefore, total investment tends to decrease, which would affect the economy adversely. If the situation remains unchecked, the adverse effect on the economy, such as declining Gross Domestic Product (GDP), the overall health of the economy may be in danger.

In 2005 and 2006, the annual base lending rate was maintained at $6.00 \%$ as there were not many initiatives taken by the government to encourage foreign direct investment in Malaysia (Tan, 2008). However, these low interest rates had encouraged more locals to purchase residential houses whereby the housing loan rates are low. On the contrary, the low interest rates did not seem to encourage foreign and domestic investors to engage in investment activities in Malaysia, as the returns on investment were not attractive. Hence, this issue had to be addressed and Bank Negara Malaysia adjusted the base lending rates by increasing the rates to attract more investors (Bank Negara Malaysia, 2009; Eze \& Tan 2012). The annual base lending rate was increased by 0.75 in 2007, and in the consecutive year, was sustained at 6.75. Both of these years were prosperous years with respect to property investment. In addition, investors were happy with their returns on investment, and more job opportunities were created as well.

Unfortunately, by the end of 2008, the subprime crisis took over American housing market, which prolonged to 2009, with its ripple effects on global housing markets. Thus, Bank Negara Malaysia had to decrease the base lending rate to ease the effect of the subprime crisis on Malaysians. The annual base lending rate for year 2009 was $6.50 \%$, a $0.25 \%$ decrease from prior year (Bank Negara Malaysia, 2009).

This research emphasizes the importance of interest rate, but Shiller (2007) argued that the real interest rate is not even a concept that many people use to frame their decision-making when they think about asset prices and the public hardly buys the concept of interest rate. This research argued on Shiller's (2007) statement that the investors are unaware of the interest rate that had brought significant impact in their loans and returns.

During periods of high interest rates and low demand, home sellers often offer purchase money mortgages to potential buyers at below-market interest rates. In similar environments, homebuilders often buy down the interest rates on the first one to five years of loans to purchasers of homes in the new development. The increase in interest rates causes borrowers to make higher repayments and face rising debt obligations (Ting, 2006; Pebe, et al. 2011). Nevertheless, the interest rates perceived by property investors when deciding to purchase a property is low as investors have to consider whether they are able to finance the loans for their desired property. There tends to be the existence of inverse relationship between real estate market values and interest rates. When housing market values are high normally, the interest rates are low. Conversely, when the real estate market is low the interest rates are high. Hence, the proposed hypothesis:

H6: Low interest rates will have a positive influence on investors' decision to purchase a property.

\section{Research Method}

According to Sekaran (2003) studies that engage in explaining the nature of certain relationships or establish the difference among certain groups or the independence of two or more factors in a situation should be researched carefully with detail arguments and hypotheses (see also Eze et al. 2012; Eze, et al. 2011).

In this study, the data will be obtained from primary or secondary sources. Primary data refers to information obtained firsthand by the researcher on the variables of interest for the specific purpose of the study. Sources of primary data are questionnaires, observations, interviews, case studies and portfolios. 
Secondary data refer to information gathered from sources already in existence. Examples of secondary data include company records or archives, government publications, industry analyses offered by the media, web sites, the Internet, and so on.

Survey questionnaire will be used to collect data in this study, and the questionnaire will be divided into two sections; Section "A" for demographic variables and Section, $B$ for statements and questions on the conceptual variables (Kwan \& Eze 2012; Eze \& Kam 2001). Section A covers questions on age, race, occupation, income level and other personal information. Meanwhile, questions in Section B are based on the independent variables and dependent variable including questions on investors' decision-making, risk of investment, inflation hedge, property prices, real income, mortgage finance and interest rates. Section B will comprise 42 questions. Most of the questions in the questionnaire will be developed based on relevant literature review (Quek \& Eze 2012; Tan \& Eze 2010).

\section{Conclusion}

This paper presented a detailed review of the key indicators in deciding to buy a real estate in Malaysia. We believe that the materials in this paper would enable prospective buyers' to make informed decision in their real estate buying process. This paper also provides information that will enable key players in the industry: government agencies, brokers, and banks to determine specific guidelines and approaches that enhance purchase decisions for investors. The final output of this study will highlight critical findings that would be useful to players in related industries.

\section{References}

Allen, F. \& Gale, D. (2000). "Financial Contagion," The Journal of Political Economy, 108 (1), 1-33

Ballesteros, M. M. (2002). "Rethinking Institutional Reforms in the Philippine
Housing Sector," Philippine Institute for Development Studies (PIDS) Discussion Paper No. 2002-16, Makati City, Phillipines.

Bank Negara Malaysia. (2009). 'Bank Negara Malaysia Economic Update 2009,' Kuala Lumpur: Bank Negara Malaysia.

Beng, T. C. \& Eze, U. C. (2010). "Determinants of Mobile Payment Usage in Malaysia: A Conceptual Perspective," Journal of Electronic Banking Systems, 2010, article ID 374494, 9.

Boon, B. (2005). "The Availability and Usefulness of Real Estate Data in Eastern Asia - A User's Perspective," IMF/ BIS Conference on Real Estata Indicators and Financial Stability. [Online], [Retrieved January 16, 2010], http://www.bis.org/publ/bppdf/bispap21 h.pdf

Brueggerman, W. B., Chen, A. H. \& Thibodeau, T. G. (1984). "Real Estate Investment Funds: Performance and Portfolio Considerations," Real Estate Economics, 12 (3), 333-354.

Bunton, D. S. (2008). 'The Boom and the Bust of the US Real Estate Market: What Went Wrong and the Lessons We Learned,' The Appraisal Foundation, Washington DC.

Chen, M. C., Kawaguchi, Y. \& Patel, K. (2004). "An Analysis of the Trends and Cyclical Behaviours of House Prices in the Asian Markets," Journal of Property Investment \& Finance, 22 (1), 55-75.

Christudason, A. (2004). "Common Property in Strata Titled Developments in Singapore: Common Misconceptions," Property Management, 22 (1), 14-28.

Clayton, J., Ling, D. C. \& Naranjo, A. (2008). "Commercial Real Estate Valuation: Fundamentals Versus Investor Sentiment," Journal Real Estate Financial and Economics, 38 (1), 5-37.

Corgel, J. B., Smith, H. C. \& Ling, D. C. (1998). Real Estate Persepctives- An Introduction to Real Estate, (3rd Ed), Irwin/McgrawHill, Boston, MA. 
Davidson, A. (2008). "Buying PropertyMalaysia My Second Home," [Online], [Retrieved February 17, 2012], http://www.mm2h.com/

Dunhill, J. (2009). 'Malaysia Property - A Robust Boom Ahead,' [Online], [Retrieved February 17, 2012], http://www.estate123.com/reviews_articl es/article_review_detail.aspx?a_id=A

Eze, U. C. (2004). "A Contextual Perspective of E-Commerce across Borders and Industries: Comparing Perceptions of the Financial and IT Industries in Singapore and Nigeria," Doctoral Thesis, Nanyang Technological University, Singapore.

Eze, U. C. \& Beng, T. C. (2012). "Credit Card Debt among Young Malaysians: A Conceptual Framework," In the Proceedings of the 2012 International Conference on Information, Management, and Technology Research (ICIMTR2012), 21-22 May, Malacca, Malaysia, 597-602.

Eze, U. C., Kwan, P. Y. \& Wamala, F. (2011). 'Key Determinants of Purchase Intentions for Proton Automobiles,' In the Proceedings of the International Conference on Marketing Studies (ICMS2011), September, 9-11, Kuala Lumpur, Malaysia, 1-15.

Eze, U. C., Tan, C. B. \& Yeo, A. L. Y. (2012). "Purchasing Cosmetic Products: A Preliminary Perspective of Gen-Y," Contemporary Management Research, 8 (1), 51-60.

Fama, E. F. \& Schwart, G. W. (1977). "Asset Returns and Inflation," Journal of Financial Economics, 5 (2), 115-146.

Glascock, J. L. \& Davidson, W. N. (1995). Performance Measures of Real Estate Firm Common Stock Returns. In Schwartz, \& Kaplan (Eds.), Real Estate Research Issues, 143-156, Kluwer Academic Publishers, Boston, MA.

Glindro, E. T., Subhanij, T. Szeto, J. \& Zhu, H. (2008). "Determinants of House Prices in Nine Asia- Pacific Economies," BIS Working Papers. 263, 26-29.
Hood, J. K. (1999). "The Determinants of Home Ownership: An Application of the Human Capital Investment Theory to the Home Ownership Decision," The Park Place Economist, 7, 39-50.

Hui, H.- C. (2008). "Transmission Channels Linking Real Estate Shocks with Macroeconomic Performance: Evidence from Malaysia," Nottingham Univ. Business School Malaysia Campus Research Paper No. 08-09. [Online], [Retrieved February 17, 2012], http://ssrn.com/abstract $=1146404$ Publisher

Ibrahim, I. Sundarasen, S. D. D. \& Hj. Ahmad Shayuti, A. F. (AF 2009). "Property Investment and Inflation- Hedging in Residential Property: The Case of District of Gombak, Selangor D.E.," IUP Journal of Applied Finance, 15 (2), 38-45.

Iossifov, P., Cihak, M. \& Shanghavi, A. (2008). "Interest Rate Elasticity of Residential Housing Prices," IMF Working Paper, WP.08 (27), 1-32.

Kamarudin, N. \& Lim, C. Y. (2005). Ascertaining Disposal Price of Commercial Properties with Guidance from the Property Market. Real Estate Educators and Researchers (REER) Association Malaysia 1st Annual Conference \& General Meeting 2005 (Pp.1 - 11). September 26 - 272005 Kuala Lumpur: Universiti Teknoloi Malaysia.

Kam, T. S. \& Eze, U. C. (2001). "The Influence of Enterprise Structure and Strategy on the Level of E-Commerce Deployment in Singapore Enterprises," Journal of Global Information Technology Management, 4 (2), 38-54.

Kwan, P. Y. \& Eze, U. C. (2012). "The Influence of Quality, Marketing and Knowledge Capabilities in Business Competitiveness," International Journal on Innovation and Learning, 11 (3), 288-307.

La Paz, P. T. (2003). "Determinants of Housing Prices in Spanish Cities," Journal of Property Investment \& Finance, 21 (22), 109-135. 
Liow, K. H., Ibrahim, M. F. \& Huang, Q. (2006). "Macroeconomic Risk Influences on the Property Stock Market," Journal of Property Investment \& Finance, 24 (4), 295323.

Mera, K. \& Renaud, B. (2000). Asia's Financial Crisis and the Role of Real Estate, M. E. Sharpe, Inc., New York.

Mufson, S. (2010). "In China, Fear of a Real Estate Bubble," The Washington Post. [Online] [Retrieved March 8, 2010], http://www.washingtonpost.com/wpdyn/content/article/2010/01/10/AR2010 011002767.html?hpid=topnews

Opoku, R. A. \& Abdul-Muhmin, A. G. (2010). "Housing Preferences and Attribute Importance among Low-Income Consumers in Saudi Arabia," Habitat International, 34 (2), 219-227.

Pebe, M., Eze, U. C., Yeow, J. A. \& Lim, K. P. (2011). "Credit Card use Patterns among Working Adults in Batswana," International Journal of Social Science Economics and Arts, 2 (2), 81-88.

Petrov, K. (2008). "Is Real Estate a Good Hedge Against Hyperinflation?," [Online], [Retrieved February 17, 2012], http://whiskeyandgunpowder.com/is-realestate-a-good-hedge-againsthyperinflation/

Poong, Y. S., Eze, U. C. \& Talha, M. (2009). "B2C E-Commerce in Malaysia: Perceived Characteristics of Innovating and Trust Perspective," International Journal of Electronic Business, 7 (4), 392-427.

Pukthuanthong-Le, K. \& Roll, R. (2009). "Real Interest Rates, Expected Inflation, and Real Estate Returns: A Comparison of the U.S. and Canada," [Online], [Retrieved February 17, 2012],

http://papers.ssrn.com.ezproxy.lib.monash .edu.au/sol3/papers.cfm?abstract_id=1364 210\&http://scholar.google.com.au/ scholar?cluster $=1689096971900145851 \&$ $\mathrm{hl}=\mathrm{en \& as} \_$sdt $=0,5$

Rönnqvist, D. \& Mattiasson, M. (2009). "The Small House Market in the Stockholm
Region: : A Study of the Impact of Macroeconomic Factors," Högskolan i Jönköping/IHH, Nationalekonom Bachelor Thesis 2009, [Online], [Retrieved March 8, 2010],

http://www.essays.se/essay/28084ca6b0/

Sahni, S. \& Phadnis, P. (2008). "Real Estate Sector - The India Story," The 14th Annual Coference of the Pacific Rim Real Estate Society. [Online], [Retrieved April 8, 2010] Pacific Rim Real Estate Society. http://www.prres.net/papers/Sonia\%20_ Real_Estate_Sector_The_India_Story.pdf.

Sang, Q. A. \& Eze, U. C. (2012). "Assessing Key Factors in Consumers' Evaluation of Product and Service Quality," International Journal on Innovation and Learning, 11 (4), 415-435.

Sekaran, U. (2003). 'Research Methods for Business: A Skill Building Approach,' (4th Edition). Wiley, Hoboken, $N J$.

Shiller, R. J. (2007). "Low Interest Rates and High Asset Prices: An Interpretation in Terms of Changing Popular Economic Models," [Online] [Retrieved November 23, 2009]

http://www.nber.org.ezproxy.lib.monash.e du.au/papers/w13558.

Shim, G. Y., Lee, S. H. \& Kim, Y. M. (2008). "How Investor Behavioral Factors Influence Investment Satisfaction, Trust in Investment Company, and Reinvestment Intention," Journal of Business Research, 6 (1), 47-55.

Shuid, S. (2004). "Low Medium Cost Housing in Malaysia: Issues and Challenges," APNHR Conference 2004. [Online], [Retrieved February 7, 2010] The Freja Project website: http://www.frejaprogram.org/www1/Mal aysia_low $\% 20$ cost $\% 20$ housing.pdf.

Sipan, I., Mohd. A. H. \& Cheok, B. K. (2005). 'The Significance of Property Sector Diversification and Regional Diversification for Property Investment,' First Real Estate Educators and Researchers Malaysia (REER) Seminar. [Online], [Retrieved February 7, 
2010], Universiti Teknologi Malaysia website: http://eprints.utm.my/1156/.

Tan, T. H. (2008). "Determinants of Homeownership in Malaysia," Habitat International, 32 (3), 318-335.

Tharachai, T. (2009). 'Factors Affecting Property Values,' [Online], [Retrieved February 17, 2012], http://www.thailandproperty-

guide.com/?p=news $/$ article\&NewsID=882

The Economist. (2001). 'Malaysia Housing Price Index,' [Online], [Retrieved February 17, 2012], http://www.economist.com/markets/bigm ac/

Ting, K. H. (2006). "Impact of the Asian Financial Crisis on Corporate Real Estate Disposals," Journal of Corporate Real Estate, 8 (1), 27-37.

Toscano, R. (2007). "Real Estate as an Inflation Hedge, or More to the Point, Not," [Online], [Retrieved February 17, 2012], http://piggington.com/user/rich

Wells, W. D. (1993). "Discovery-Oriented Consumer Research," Journal of Consumer Research, 19 (4), 489-504.

Wong, J. (2009). 'Repercussions of the 5\% RPGT,' [Online], [Retrieved February 17, 2012],

http://starproperty.my/PropertyGuide/Le gal $/ 1156 / 0 / 0$

Wong, J. T. Y. \& Hui, E. C. M. (2008). "The Myth of Property Prices: On the Psychology of Sellers and Buyers," Property Management, 26 (3), 171- 190. 